\title{
The Methods of Preventing Water Hyacinth as Aquatic Pollution in Lake Toba Caused by Agricultural Waste
}

\author{
Muhammad Irham Taufik Nasution, Sutan Muhamad Sadam Awal, and Dhio Meydi Permana
}

\begin{abstract}
Water hyacinth (Eichhornia crassipes) is a type of aquatic plants afloat. Reproduction of hyacinth is very high and fast so it is considered a weed that can damage the aquatic environment. Water hyacinth can grow in all types of waters, such as lakes, rivers, swamps, and even waters that have low nutritional content. Hyacinth thrives in the Lake Toba, Lake Toba which is one of the tourist destinations of the world. The presence of water hyacinth in the Lake Toba region threaten the beauty of one of the tourist destinations Indonesia pride. The content of nutrients in the Lake Toba which is high because of the activity of the agricultural waste thrown directly into Lake Toba adds to the growth of water hyacinth. By looking at the State of the Lake Toba which threatens the growth and beauty of Eichhornia crassipes is very high is a problem that must be solved together. The methode of finishing this paper is journal and book reviewed. This paper will discuss about steps that can be taken to preserve the Lake Toba from agricultural waste pollution.
\end{abstract}

Index Terms-Water hyacinth, aquatic enviromental, agricultural waste pollution, preserve.

\section{INTRODUCTION}

Lake Toba is the largest lake in Indonesia and Southeast Asia. The surface of the lake at a height of 903 meters above sea level, and Water Catchment Area (DTA) 1.981 meters above sea level. The Area of Lake Toba which is $1,130 \mathrm{Km}^{2}$ with a maximum depth of Lake is 529 yards. The total Catchment area (DTA) of Lake Toba approximately is $4.311,58 \mathrm{Km}^{2}$ [1]. Annual precipitation in the Lake Toba Catchment ranges from 1,700 to $2,400 \mathrm{~mm} /$ year. While the peak of the rainy season occurs in the months of November and December with rainfall between 190-320 mm/month and the peak of the dry season occurs during the months of June-July with rainfall ranging from $54-151 \mathrm{~mm} / \mathrm{month}$. Water entering the Lake Toba comes from rainwater falling directly into the Lake and the water comes from rivers entering the Lake [2]. The water flow into Lake Toba. Watershed (Catchment Area) above consists of 26 Sub DAS, namely: Aek Sigumbang, Aek Haranggaol, Situnggaling, Naborsahon, Tongguran, Gopgopan, Mandosi, Aek Bolon, Simare, Halion, Sitobu, Siparbul, Pulau Kecil, Silang, Bodang, Parembakan, Tulas, Aek Ranggo, Simala, B. Sigumbang, B. Bolon, Silabung, Guluan, Arun, Simaratuang, Sitiung-tiung [3].

Lake Toba's water becomes a source of life for the local community. The Lake is located in the Batak Land is

\footnotetext{
Manuscript received May 26, 2015; revised September 16, 2015.

The authors are with Bogor Agricultural University, Bogor, Indonesia (email: islamicstudent11@gmail.com, sutan235@gmail.com, dhio.dmp@gmail.com).
}

becoming a source of life-support of drinking water, energy sources, and so on. Not only humans, biota such as terrestrial animals and plants get water intake from Lake Toba. In addition, aquatic biota in Lake Toba is very diverse. Lake Toba region is also a fertile region, volcanic soil, it should be restored to play a role in establishing national food sovereignty. Lake Toba area potentially as a source of diverse food and vegetables for the community of North Sumatra area. However in the past lately, particularly since the 1990s, generally perceived the presence of loss of quality and atmosphere of the beauty of the Lake Toba region. Severe damage has not only touched the environment of Lake Toba but also the body of water of Lake Toba [4].

A number of water hyacinth which grow very lush became a benchmark that the water quality of Lake Toba declined. Hyacinth annoy some ecosystems because of growth, the plant is able to adapt to extreme changes based on water levels, changes in the availability of nutrients, $\mathrm{pH}$, temperature, and toxins in the water. The growth of water hyacinth in the Lake Toba is very fast, this is due to the water of Lake Toba which contains nutrient increasingly rapid growth of water hyacinth, because water contains high-nutrient Lake Toba, rich in nitrogen, phosphate and potassium which cover the surface of the Lake in the calm water, as in Baktiraja which is situated on the edge of the Lake. This occurs because the content of agricultural activity that intentionally dumped agricultural waste into water of Lake Toba. If this is left for granted, Lake Toba which became the source of life in the Batak Land will be covered by water hyacinth.

\section{The CURRENT StATE of LAKE ToBA}

Lake Toba where is located in North Sumatra is one of the country's most valuable asset and one of the important tourist destination after Bali and Lombok, so it is a pride for the region. Lake Toba is ruled as one tourist destiny, because of the presumption for has a beautiful natural panorama. But, now the beauty of Lake Toba was disturbed due to the exploitation of its natural resources, both terrestrial and aquatic areas around them. The Water entering the Lake Toba comes from rivers and rain water promptly. The distribution of rivers in the catchment is in Fig. 1 below:

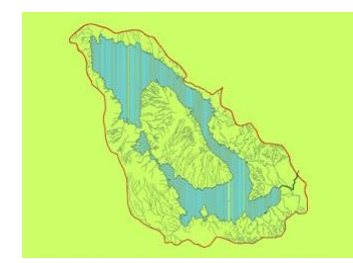

Fig. 1. Distribution map of rivers in the catchment of Lake Toba (source: LIPI) [5]. 
In General, the activity of Batak communities lives in surrounding Lake toba moves on the agricultural sector. This communities goes to plant paddy and others. There are also so many cattle, nemed cows, pigs, ducts, goats, and chickens which support their life. Fishing is carried out most of the population around the Lake Toba. The crafts sector also developed such as weaving, rattan, wood carving, pottery, which is related to tourism. However, the activities of the community in the catchment or Lake area produces waste that pollutes the waters so that physical-chemical quality of the waters of Lake Toba undergo changes [6].

Water hyacinth is starting to look to cover the surface of Lake Toba. Agricultural wastes are dumped directly into the catchment area causing high water nutrient content so hyacinth grows. Though the rate of growth of water hyacinth is the highest of the other plants. If this does not be overcomed, the Lake Toba will be covered by water hyacinth. These cases had occurred in Lake Victoria, Africa, covered by water hyacinth. Their government even asked the World Bank to help resolving this problem.

Water hyacinth is a plant that is greedy of oxygen, this will have an impact on the state of water BOD and COD. Agricultural wastes communities around Lake Toba is discharged directly into the waters of the lake would affect the levels of ammonium in the waters of Lake Toba. The Water Quality of Lake Toba conditions can be seen in the graph below:

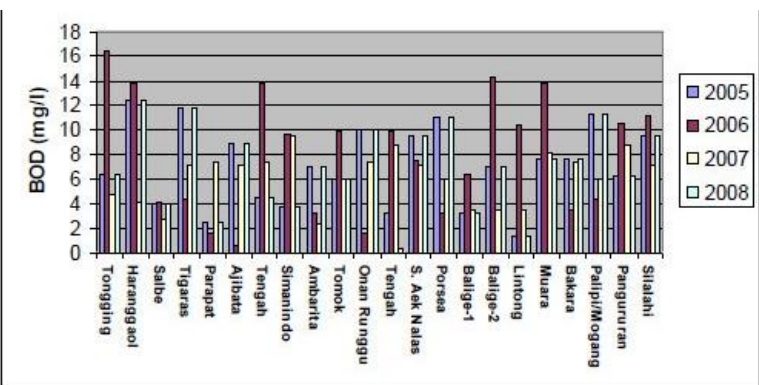

Graph 1. BOD waters of Lake Toba (Source : Environment Agency of North Sumatra Province in 2005 , 2006, 2007 , 2008).

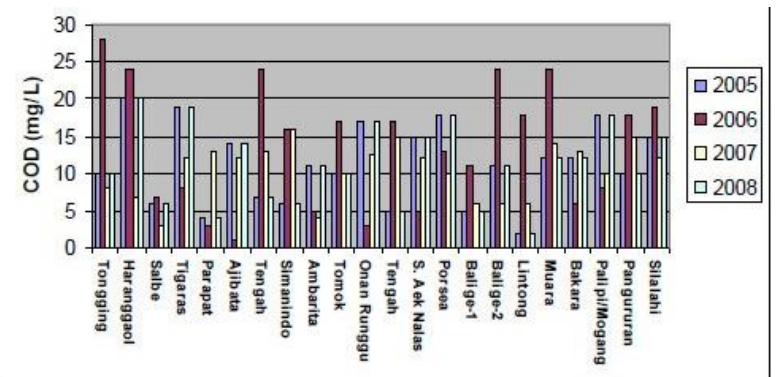

Graph 2. COD waters of Lake Toba ( Source : Environment Agency of North Sumatra Province in $2005,2006,2007,2008)$.

These graph tell that the water in Lake Toba has been influenced by other material which can destroy the lake. The most prevalent source of agricultural water pollution is soil that is washed off fields. Rain water carries soil particles (sediment) and dumps them into nearby lakes. Too much sediment can cloud the water, reducing the amount of sunlight that reaches aquatic plants. It can also clog the gills of fish or smother fish larvae. In addition, other pollutants like fertilizers, pesticides, and heavy metals are often attached to the soil particles and wash into the water bodies, causing algal blooms and depleted oxygen, which is deadly to most aquatic life. Farmers and ranchers can reduce erosion and sedimentation by 20 to 90 percent by applying management practices that control the volume and flow rate of runoff water, keep the soil in place, and reduce soil transport. This case make the water hyacinth grows flourishly [7]. Nowadays Lake Toba look so terrible, the water hyacinth grows even nearby the hotel. That can make the tourist feel bad about Lake Toba. The proof that the water hyacinth is in Fig. 2 below:



Fig. 2. Water hyacinth grows flourishly in Lake Toba (Source Mongabay.co.id)

\section{PREVEntion Methode}

Water hyacinth waste polluting Lake Toba must be overcomed immediately. The growth of water hyacinth which is very quickly become a major problem that can damage the Lake Toba beauty. Organic waste pollution from agricultural activity remains of the community can add power to grow hyacinth. Prevention methode that can be done at are as follows:

\section{A. Physical Methods}

This method is carried out in related to the prevention of physical contact, by means of pick-up and the water hyacinth plants collected by hand without the help of other supporting or with bare hands [8].

\section{B. Chemical Methods}

This method is a reduction performed using chemical herbicides, how to spray the chemical solution in the area or region growned by water hyacinth.

\section{Method of Mechanical}

This method is implemented countermeasures in related to the tool, by plowing or lift the water hyacinth from the ground or from the periphery where the operator of affordable tools for lifting.

\section{Biological Methods}

This method is carried out with a contact prevention nature without human intervention, by way of spreading the organism eaters (herbivorous). Organisms are commonly used in a variety of lake waters in Indonesia is grass carp fish.

\section{E. Combination Methods}

This method is a response to the implementation coupled with the four methods of physical, chemical, mechanical, biological and combination, the methods used in this method is compact in its work. This way will quickly finish the job, 
but caused a huge impact of mitigation activities [9].

\section{F. Social Methods}

This method works with communities. After collected water hyacinth, the communities can make different kinds of craft appropriate. But with many existing water hyacinth, it is impossible to be produced by individually. Samosir regency government will make policies that exploit water hyacinth in Lake Toba as a bag for elementary school until high school. This will be benefit especially those who unemployment. Besides being able to cope with environmental problems, this method also can reduce the problem of poverty due to the lack of jobs available.

In addition to methods to reduce or even eliminate the water hyacinth in Lake Toba, prevention of sewage into Lake Toba also be done to prevent the return of water hyacinth. Agricultural waste that flows into Lake Toba caused the proliferation of water hyacinth that there should be prevention Prevention to do is:

1) Conducting outreach to residents around Lake Toba to not dispose of waste and inorganic and orgnic directly to the catchment and lake.

2) Using a water filtration technology so that other materials cannot come flowing into Lake Toba.

3) The government made strict rules for people who throw garbage directly into the lake.

4) Conduct outreach to recycle agricultural waste properly.

\section{THE POTENTIAL OF WATER HyACINTH}

The potential of water hyacinth are :

\section{A. Bioetanol}

Water Hyacinth is plentiful in the water bodies in the tropics and the biomass is rather distributed in its geographical occurrence. Ethanol production from this feedstock has several technical challenges including biomass collection and preprocessing and decentralized plants for ethanol production may be more appropriate for such feedstock. Here we had demonstrated that it is possible to achieve almost $71 \%$ efficiency in saccharification of water hyacinth biomass with very crude and cost effective methods for pretreatment and onsite enzyme production [10].

\section{B. Cheap-Protein Source}

The water hyacinth (Eichhornia crassipes) could be an inexpensive source of protein for animal, and possibly human, nutrition. The fibre is usable for ruminants. This is a pilot study on processing the plant. The samples used came from Egypt. The tissue contains many air-filled intercellular spaces and soaks up water, but is also tough as a result of fibres. It contains sharp needles formed by Ca-oxalate. Though the concentration is not high enough for toxicity, the needles could harm the digestive tract." Owing to the tissue's toughness much energy must be spent in chopping it, which results in many destroyed cells. Polyphenoloxidases are activated and the resulting quinones react with the protein, making it indigestible. So the native enzymes have to be inactivated before further processing. This could be done by adding low quantities of sulphite. Lactofermentation, a prerequisite for silage production, is possible, but only after adding sugar and suppressing mould growth [11]

\section{Textile Product}

Water hyacinth, the worst aquatic weed was found to be highly impossible to eradicate from the water ways, though its quest for nutrients has given a possible way for its usage in phytoremediation. In the last few years great interest has been shown for the research of water hyacinth as a good candidate for pollutant removal or even as a bioindicator for heavy metals in aquatic ecosystems. In this present article the detailed biosorption efficiency of the water hyacinth in the removal of various pollutants present in textile waste water was enumerated. In conclusion, water hyacinth has high removal rates for various dye stuffs and heavy metals like iron $(\mathrm{Fe})$, zinc $(\mathrm{Zn})$, copper $(\mathrm{Cu})$, chromium $(\mathrm{Cr})$, cadmium $(\mathrm{Cd})$, manganese $(\mathrm{Mn})$, mercury $(\mathrm{Hg})$ and arsenic (As) from aqueous solutions. Very few reports are available in the literature on the direct application of water hyacinth and its derived products in removal of dyes and heavy metals from textile effluent as well as from wastewater [12].

\section{Methan-Recovery}

The viability of methane recovery systems from water hyacinth with recourse to whole-cell immobilization technology along with alkali pretreatment has been experimentally demonstrated in this investigation. A threestage immobilized system can be designed with an alkalipretreatment stage $\left[3.6 \% \mathrm{Na} 2 \mathrm{C} 03+2.5 \% \mathrm{Ca}(\mathrm{OH})^{*}\right.$, 24-h HRT] followed by an open acid reactor (2.1-day HRT) and closed immobilized methane reactor (12-h HRT). The reactors with crushed insulation brick of 500-3000 pm support mature in 15-18 weeks and operate at an organic loading rate of $20 \mathrm{~kg} \mathrm{COD} / \mathrm{m} 3$ day, facilitating steady-state COD conversion of $62-65 \%$ and TVA conversion of $91-95 \%$ to provide gas productivity of 4.08-5.36 L/L reactor volume/day with $82 \%$ methane. A gas yield of $50 \mathrm{~L} / \mathrm{kg} \mathrm{WH} /$ day can be obtained from this system [13].

\section{E. Nutrient Removal}

Water quality improved around the water hyacinth mats. Moreover, there were no significant adverse effects on macrozoobenthos and zooplanktons (cladocerans and copepods) of the ecological engineering using of water hyacinth. The results confirmed the tremendous potential to use water hyacinth for nutrients removal in the entrophic lakes such as Lake Dianchi [14].

\section{CONClusion}

Lake Toba is the Indonesian national asset that is essential for tourism in Indonesia. The natural beauties of Lake Toba add the attractive of local tourist and foreign tourists to come to this natural lake. Growing water hyacinth with lush natural beauty of Lake Toba reduce this natural lake. Agricultural waste are directly discharged into the catchment area ofthe lake and directly adds to the growing power of the water hyacinth. Many ways have been done to address this problem. The problem of pollution of Lake Toba from agricultural 
waste is not a one-sided problem, but a common problem that must be overcome or lake pride of Indonesia will be filled.

\section{ACKNOWLEDGEMENT}

First of all, we would like to thank the Almighty God, for His blessing upon the completion of this Paper as Preparation of Papers for International Journal of Environmental Science and Development (IJESD) 2015. We would also like to express my sincere respect and gratitude to Suprianto, S. Tp, M. Kom. respectively as our supervisor for his patience, encouragements, and guidance during the completion of this paper in checking and revising the manuscripts. We would like to thank to Faculty of Agricultural Engineering expecially to the Department of Mechanical Biosystem Engineering where facilitate us to finish this paper. And we would like to thank to International Journal of Environmental Science and Development (IJESD) commitee who given us the opportunity to submit this paper. Finally, and most importantly, We would like to thank Our Family. Their support, encouragement, quiet patience and unwavering love were undeniably the bedrock upon which the past years of our life have been built. Their tolerance of our occasional vulgar moods is a testament in itself of Their unyielding devotion and love. Their faith in us and allowing us to be as ambitious as we wanted. It was under their watchful eye that we gained so much drive and an ability to tackle challenges head on so that we could finish this paper.

\section{REFERENCES}

[1] L. Victor, "Tourism area life cycle in lake Toba," Indonesian Journal of Geography, vol. 44, no. 3, pp. 150-160, December 2012.

[2] United Nations for World Tourism Organisation. (2015). [Online]. Available: http://www.unwto.org

[3] B. S. Utara, Pengkajian Teknis Pemanfaatan Sumber Daya Alam dan Pengelolaan Lingkungan Hidup Kawasan Danau Toba, pp. 15-34, 2000.

[4] T. A. Barus, Pengantar Limnologi Studi tentang Ekosistem Air Daratan, Medan : USU Press, pp. 223-230, 2004

[5] T. A. Barus, S. S. Sinaga, and R. Tarigan, "Produktivitas primer Fitoplankton dan hubungannya dengan faktor fisik-kimia air di perairan Parapat Danau Toba," Jurnal Biologi Sumatera, vol. 3, no. 1, pp. 11-16, 2008.

[6] M Sherlly, "Analisis Adaptasi desain bangunan fasilitas wisata terhadap elemen-elemen regional dengan menggunakan teori regionalisme kritis untuk meningkatkan sense of place kawasan (Studi kasus: Kawasan wisata danau Toba)," Jurnal Semai Teknologi, vol. 4, no. 2, pp. 134-144, December 2010.

[7] E. D. Ongley, "Control of water pollution from agricultural," presented at the ISSN GEMS Water Collaborating Centre, Burlington, Canada, 1996.

[8] J. R. Dojildo and G. A. Best, Chemistry of Water and Water Pollution, New York, Ellis Horwood Limited, pp. 17-19, 1992.
[9] Fardiaz, Polusi Air dan Udara, Yogyakarta, Kanisius, pp. 123-127, 1992.

[10] U.S. Aswathy, Rajeev K. Sukumaran, G. Lalitha Devi, K. P. Rajasree, R. R. Singhania, and A Pandey, "Bio-ethanol from water hyacinth biomass: an evaluation of enzymatic saccharification strategy," Bioresource Technology, vol. 101, pp. 925-930, 2010.

[11] S. Bolenz, H. Omran, and K. Gierschner, "Treatments of water hyacinth tissue to obtain useful products," Biological Wastes, vol. 33 , pp. 263-274, 1990.

[12] E. Sanmuga Priya and P. Senthamil Selvan, "Water hyacinth (eichhornia crassipes) - An efficient and economic adsorbent for textile effluent treatment-A review," Arabian Journal of Chemistry, pp. 25-32, July 2013.

[13] A. P. Annachhatre and P. Khanna, "Methane recovery from water hyacinth through whole-cell immobilization technology," Biotechnology and Bioengineering, vol. 29, pp. 805-818, 1987.

[14] Z. Wanga, Z. Zhang A, J. Zhang, Y. Zhang, H. Liu, and S. Yan, "Large-scale utilization of water hyacinth for nutrient removal in Lake Dianchi in China: The effects on the water quality, macrozoobenthos and zooplankton," Chemosphere, vol. 89, pp. 1255-1261, 2012.

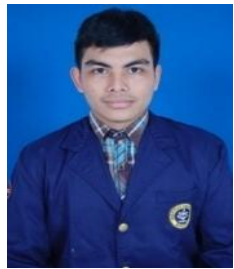

Muhammad Irham Taufik Nasution was born in Indonesia, on July 17,1995 . He is an undergraduate student of mechanical and biosystem engineering, Faculty of Agricultural Technology, Bogor Agricultural University, Indonesia. As a student, he has been actively involved on many organizations student. At Bogor Agricultural University, he actives as a staff of Research and Development Division (RnD) of Agricultural Engineering Student Association (Himateta). He is also one of Bidikmisi Scholars.



Sutan Muhamad Sadam Awal was born in Bogor on Aguust 13, 1995. He lives in Setu Village Leuwiliang Bogor. He graduated from SMA 1 Leuwiliang. Now he is studying in Bogor Agricultural University Department of Mechanical and Biosystem Engineering. He is very friendly to the other so he has many friend from his department or others department. He has some skill about

programming and electronic and also has a leadership skill. Now he got PPSDMS Scholarship, and there he has to prepare himself to be a future leader and has good loyality to his country as a student. He reacived some reward. Be a second champion at physic olympiade in Bogor City, Semifinalist of nucleon physic in Malang University, and also champion of some speech contest in my junior high school. His future plan is to be a great engineer in robotic for agriculture. And he wants to be a technopreuner, so he can help the poor man and others people who need help in financial.

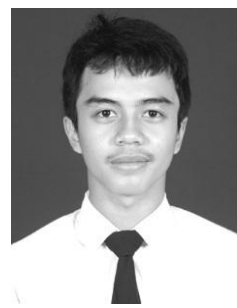

Dhio Meydi Permana was born in Bogor on December 11,1995 . He is an undergraduate student from Mechanical and Biosystem Engineering, Bogor Agricultural University. $\mathrm{He}$ has been actively involved in many Organizations. He is the staff of Campus Social and Responsibility of Agricultural Engineering Student Association (HIMATETA). He is also one chief of Engineering Language Club. 